Albutt, (Sir) Thamas Clifford Palissy, Pacon, and the

revival of natural science

ERINDALE COLLEGE LIBRARY

QH

31

$\mathrm{P}_{3} \mathrm{H}_{6}$ 


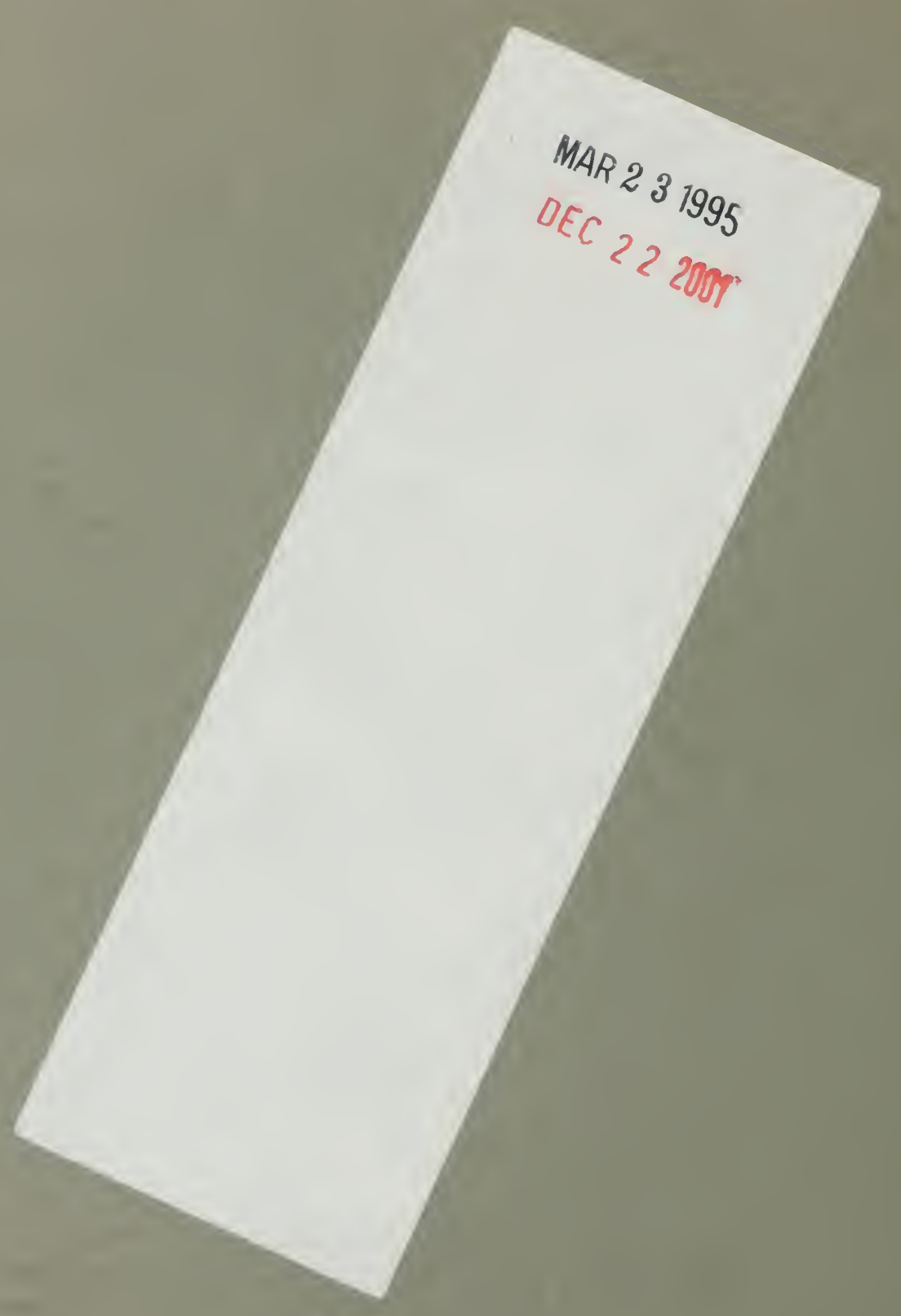




\title{
PALISSY, BACON, AND THE REVIVAL OF NATURAL SCIENCE
}

\author{
By Sir THOMAS CLIFFORD ALLBUTT, K.C.B., F.R.S.
}

\section{Read at the International Historical Congress, April, 1913}

Christendom rose as slowly out of the Middle Ages as out of the Dark Ages. If in the Dark Ages our fathers had to strive against chaos, ruin, and savage violence, the Middle Ages had to emerge from that stage of iron discipline whereby the nations were consolidated, formed into fighting units, and cnabled to work out their several survivals in the new Europe. Tlese disciplines and functions were therefore provisional and temporary; infortunately the machineries of society, as of manufacture, are apt to outlast the conditions of their establishment, and to petrify into a framework so rigid as to stop further growth. Thus it was with the machinery of the Middle Ages - the means of survival in the day of its development; in later stages it became a material thraldom and a spiritual despotism. From the Middle Ages however, as from other periods of history, we derive this tribute to ideas; that ideas are stronger than armours of steel, that, in the long run, they are more powerful to govern, and indeed to enthrall, mankind than material systems; and as it was by the irresistible compulsion of ideas that the men of those Ages were first organized into the rudiments and shapes of nations, so by them in after times were men enslaved, in times when the ideas which had done their work should have been scrapped, but which in their stony decrepitude were almost impregnable to the boldest assailants. If we may admire the power of ideas when they lead us and inspire us, so must we learn also their sinister effects when having served their purpose they oppress us with the dead hand. If we admire them in the air as pillars of fire, so we may fear them though gathered under the earth. If they ride the storm, they drive the volcano. Happily however ideas, these strongest forces of civilisation, are not all on one side; so that by the alliance of some of them we may abate the supremacy of the rest. Still even thus, bloody as the conflict was, the rise of Christendom out of the Middle
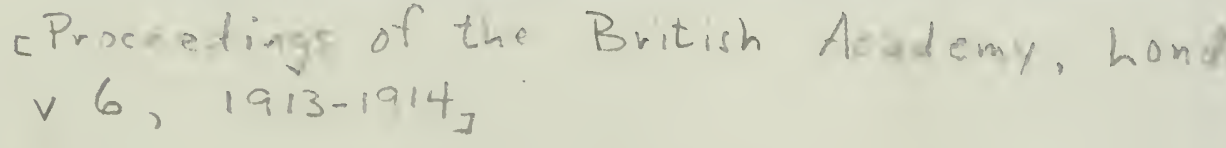


\section{PROCEEDINGS OF THE BRITISH ACADEMY}

Ages was as slow as it was fitful. Jurisprudence, humanism, universities, printing, science-all these conditions made for free thought; but the Sturmgeister and their books were burned, and trimmers preferred obscurity to martyrdom. If on the one side Peter Lombard and St. Thomas Aquinas displaced the Bible, Melancthon on the other preferred Sacrobusto's De Sphaera Mundi to the De Revolutionibus Orbium celestium. Copernicus himself nursed his ideas in secret till his death-bed; even then 'Tycho dare not preach them, and Bruno, who did dare it, was sent to the stake. Meanwhile with imprisoned ideas the ground was shaking; and in Italy where, under Pope and Emperor, some sense of unity had grown up and the need of the iron scaffolding of despotic ideas was felt less than in new and inchoate states of society, attacks on the old by the insurgent ideas were becoming a less perilous warfare-at any rate until the rising of the malignant star of Spain. In Italy for a time nature studies sprang up in some freedom; and in its universities free thought and natural knowledge made no little progress. Medicine, especially on its surgical side, was vindicating the method of progress from facts to facts, as against progressions from words to words. Yet, in all our sympathy with such men as Telesio, Campanella, or Bruno, we cannot but admit that they were rather philosophizers on nature than naturalists; and even in the domain of philosophy were less weighty and powerful than Francis Bacon. Campanella must be regarded rather as the father of modern idealism than as an intellectual comrade of Galileo; his criticism was of phenomena by ideas, not of ideas by facts. But it was not by the methods of Descartes and Kant that the natural sciences were to flourish-not precisely even by the method of Bacon-valuable as these methods were in their own sphere; natural knowledge was to be discovered by humbler devotions, even by digging into the earth, as dug the potter of whom I an to speak to-day.

Like Gilbert and Galilen, Palissy was led to investigate certain problems of Physics, problems which on account of their comparative generality and simplicity had to be solved before the subtler secrets of chemistry and biology could be tackled. Yet, although as an artist his dramatic life is so familiar to us all as in this place to need no more than the briefest sketch, as a scientific pioncer Palissy is almost unknown. He was born in 1519, in Périgord, as was Montaigne in 1533. The Dordogne had then gone back from English to French; and soon after, under Henry IV, became part of the French kingdom. His native district was an important centre of the art of glass painting, and to this craft Palissy was apprenticed. 

After the fashion of his time he wandered widely as an apprentice. We know that he tramped industriously over the Pyrenees and the Netherlands, closely observing the natural features of these countries, and the various works of nature, especially earths and minerals. Glass painting however was then in decadence, and while Palissy was striving to make a poor living in a failing art a cup of glazed faience was put into his hands. With the intuition of genius he saw the way to a new craft, could he but penetrate the secret of the pastes and glazes of which the della Robbias, and the craftsmen of Urbino, Faenza, and other ateliers tenaciously held the secret. In Palissy's time no pottery was known, at any rate in provincial France, other than the coarse unglazed ware, such as the pipkins, bread-pots and the like, which still existed in the households of the youth of some of us. Now whence came this wonder-working cup? It is said from the East-from China for instance; but we need not make so large a supposition, the source of it was probably much nearer home. The feudal noble of the district of Saintonge was the accomplished Sire de Pons, who married the no less accomplished Anne de Parthenay from the court of Ferrara; and in the very year, 1539, that Palissy saw the 'coupe de terre tournée et esmaillée' the Lord of Pons had returned, with many presents, from Ferrara. It is known that Palissy had already attracted the notice of de Pons, and to him it was that Palissy afterwards' dedicated his Discours admirables. However, hereupon began Palissy's serious researches in two main directions: into the qualities and mixtures of earths, and into the chemistry of glazes. Of this stormy and dramatic period of his life, of the strife of the prescient and tenacious genius against the chiding of his own household and the ridicule of his neighbours, in the depths of poverty selling the furniture of his cottage, and the very coat from his back, to procure the materials of his research, how thus laboriously he discovered lead and tin glazes, the amalgamation and chemistry of earths, and the arts of baking and of modelling which resulted in art products now worth perhaps their weight in gold, is a story familiar to us all. Happily that was given to Palissy which jealous fortune too often denies to the discoverer-the remuneration of toil, and the recognition of his contemporaries. For the once-despised grubber in clay and potsherds became the servant of princes; and, fervent Huguenot and stubborn naturalist as he was, it was well for him that the Constable Montmorency, and by his mediation the King and Court, took him into their protection; or the little finger of the Church would have proved stronger than the loins of poverty and distress. 

By the patronage of his powerful friends Palissy found his way to Paris, which in the sixteenth century was becoming the most hidebound of European centres of learning; and it is on his work in Paris that I desire to dwell-that is to say, on his scientific work; in his art-work he is known, and even familiar, to us all.

Palissy, ignoramus as after the standards of Paris he was, yet wrote many books; books which we may peruse with deep interest. Now these books, discursive as they are, turn but little on the arts of pottery; nay, the artist may-after the fashion of the times-have deliberately chosen to keep his trade secrets to himself. The books deal chiefly with natural objects in great variety, and reveal his extraordinary personal insight and experience. I have said that his books are discursive; they are indeed unsystematic, and thus are in striking contrast to the Summae of the age. Still, they are not without a natural unity of their own, an organic as contrasted with a logical unity, the unity of a simple and unsophisticated genius engaged in direct and intimate converse with nature, unwarped by the categories of the schools. The title of his first large book is 'Recepte véritable, par laquelle tous les hommes de France pourront apprendre à multiplier et à augmenter leurs thresors; composé par maistre Bernard Palissy, ouvrier de terre, et inventeur des rustiques figulines du Roy, et de Monseigneur le duc de Montmorency, pair et connestable de France, demeurant en la ville de Saintes. La Rochelle, de l'imprimerie de Barthélemy Berton, 1563.' The first division of the book is on Agriculture, the practice of which, he says -and he was, I suppose, the first modern to say it - can be understood only by scientific study. He proceeds therefore to investigate the nature and value, I may allow myself even to say, the chemistry, of manures, and especially of marl, as dressing for the land; and gives advice on their proper applications. Forestry then attracts his notice; he sees and regrets the evils of deforestation, pleads for an economic management of woodlands, and girds at the devotion of such sources of wealth only to hunting, and like amusements. Next he brings forth the results of his wanderings over the lands of Europe; he discusses the causes of their outward forms and surfaces, demonstrates the various kinds of earth, the formation of rocks by consolidation from liquid suspension or solution, and the formation of crystals and gems by precipitations and segregations in past ages. He gives a much better definition of a salt than had hitherto been attempted, even by the alchemists. He points out that in a salt two substances combine to form, not a mechanical mixture but a new body ; a unity so close that each constituent gives conditions to the 

other. He contrasts this regeneration with the phenomena of attraction, phenomena of which again he was no inconsiderable interpreter. Chemical affinity he distinguishes from attraction, as a hidden power of combining to form new substances; attraction, on the other hand, is often between like bodies without the development of new quality; and herewith he proceeds to foreshadow a theory of universal attraction and repulsion. He studies also the results of incineration of plants; and the action of alum as a mordant. With the penetrative insight of genius, he detested the hollowness and unprogressiveness of alchemy; indeed he tells us that he had worked in the ateliers of the alchemists, and that for the most part they were humbugs, and the rest of them altogether foolish. In the veins of the earth he found no evidence that, even by the chemistry of the earth herself, metals were susceptible of transmutation. He declares the search after such chimaeras to be a disgraceful example of covetousness, and of covetousness which would defeat itself; for things are as men use them, a saw which he illustrates by an imaginary controversy between the tools of geometry and of other crafts, the compass domineering over the ruler, and so on; whereas none of these is of the slightest use without the hand of the craftsman. Then he persuades us how far is a flower-bud, with all its wondrous life, above gold and silver; and so he passes on to the wonders of the world of plants, and to speculate on the marvellous instincts of animals.

Palissy's books are full of satirical and shrewd humour, as naturally in his moods he drifts from thought to thought in what has been called a 'Mosaik-Arbeit'; and not the least of his revelations is that of his own fascinating personality.

Before the Bartholomew Jean Goujon was dead, and Palissy, who had thereupon become necessary to royal splendour, was carried off to Sedan; after the massacre, in which Ramus was deliberately slaughtered, Palissy was brought quietly back to Paris; and in $\mathbf{1 5 8 0}$ he published his really astonishing Discours admirables. The full title is as follows: 'Discours admirables de la nature des eaux et fontaines tant naturelles qu'artificielles, des métaux, des scls et salines, des pierres, des terres, du feu et des émaux. Avec plusieurs autres excellents secrets des choses naturelles; plus Un Traité de la Marne, fort utile et nécessaire pour ceux qui se mellent de l'agriculture, le tout dressé par dialogues Esquels sont introduits la Theorique et la Practique, par Mons. Bernard Palissy Inventeur des rustiques figulines du Roy et de la Royne sa mere. Paris chez Martin le jeune, à l'enseigne du. Serpent, devant le Collège de Cambray, 1580.'

Although, in spite of powerful protection, his life was in peril, yet. 

he continued to lecture in public; and it is upon this part of Palissy's activity that I desire to dwell; for it is during the years 1575-84 that he exercised his great influence upon society in Paris. At that season his eminence and notoriety must have been as great as the neglect, in part deliberate, in part oblivious, to which reactionary influences on the one hand and indifference on the other have since condemned his works and his reputation. For I find it is unknown to men of science and to historians that in this third part of the sixteenth century a great scientific naturalist was lecturing in Paris on agriculture, chemistry, mineralogy, and geology ; and this not in an abstract or dryasdust style, but vividly, with denionstrations of the natural objects themselves which in his lectures he had before him. For Palissy had formed a considerable museum, by means of which his lectures were illustrated, and whereby he endeavoured to draw forth the observing faculties of his hearers. Every object was labelled with the fullest description he could give of it-both as regards its provenance and its nature. In true humility, but perhaps with some irony, he said that he lectured in public in order that one whose education had been so defective as his own might be enriched with more facts and corrected by criticisms. In 1575-76, and again in 1584-not to mention the work of intervening years-Palissy got up a sort of scientific congress in Paris. Into the faces of the learned of his time he thrust his facts; he urged the might of the verified fact, the tests of practical experience, the demonstrations of the senses ; and these in a keen and original way. All the world went to wonder at the knowledge of a man without Latin and Greek!

How great and imposing were the audiences at these strange lectures fortunately we know directly from Palissy himself. He gives a long list of the learned and dignified persons who attended them. Physicians, who then were nearer to nature than other learned men, came in groups, and we have their names. One of them was no less a person than Ambroise Paré, First Surgeon to the King. Two of them, as we might expect, were physicians to the generous Margaret of Navarre. Besides the physicians were many Canons, Jurists, Humanists, Dukes, and others too many to quote. The Museum was always open, and the curator, who now had charge of the royal gardens as Maitre Bernard des 'luileries, scems to have been always ready to demonstrate his collections. For, says Palissy proudly, all these persons came to me, and I have challenged them to put me to the test, but I have found none to gainsay me. In the dedication of the Discours admirables to the Sire Anthoine de Ponts, Palissy says: 'J'ai dressé un cabinet auquel j'ai mis 

plusieurs choses admirables et monstrueuses, que j'ai tirées de la matrice de la terre, lesquelles rendent tesmoignages certains de ce que je dis, et ne se trouvera homme qui ne soit contraint confesser iceux veritables, apres qu'il aura vu les choses que j'ai preparées en mon cabinet, pour rendre certains tous ceux qui ne voudraient autrement adjuster foi a mes escrits . . . je prouve en plusieurs endroits la theorique de plusieurs philosophes fausse, meme des plus renommez et plus anciens, comme chacun pourra voir et entendre en moins de deux heuses, moyennant qu'il veuille prendre la peine de venir voir mon cabinet, auquel l'on vèrra des choses merveileuses qui sont mises pour tesmoignage et prouve de mes escrits, attachez par ordre ou par estages avec certains escriteaux audessouz, afin qu'un chacun se puisse instruire soi-meme: te pouvant assurer (lecteur) qu'en bien peu d'heures, voire dans la premiere journée, tu apprendras plus de philosophie naturelle sur les faits des choses contenues en ce liure, que tu ne saurais apprendre en cinquante ans, en lisant les theoriques et opinions des philosophes anciens.'

I cannot undertake to delay you by any attempt to distinguish what may be erroneous from the true teachings of Palissy; for my principal aim is to impress upon you rather his method than his results. The point is not merely that Palissy declaimed against the schoolmen, but that he built upon another foundation. Nor will I attempt even to make a catalogue of all the subjects on which this industrious and enlightened man discoursed. I will however select a few of these subjects, those which best lend themselves to an illustration of his methods; of such are his researches on watersprings-in which, by the way, I find nothing about the baguetteand his interpretation of the origin of rocks and fossils. In the chapters on Springs and Fountains he illustrates the origin of springs by an artificial hydrostatical machine, or schema, and points out that these waters must come from a height; and if it be not from a neighbouring hill then from some more distant elevation. By observation and experiment he combated the prevailing notion that springs originated in the percolation of sea-water into the earth, disproving it by the positive method of comparing the substances in solution. He declared, on the contrary, that underground waters accumulate by the permeation of rain through the strata of the earth; that so long as the strata which receive it are permeable the rain sinks, and sinks until it meets with an impermeable stratum; then it is arrested, and will be deflected towards a place where the strata crop out. None since Vitruvius had perceived this truth, and Gassendi probably got it from Palissy; who had shown further how 

by passing through certain strata water takes up saline and other soluble substances, some of which may have medicinal qualities. The heat of certain springs he attributed to the central heat of the earth. While speaking of rain, Palissy explained that the rainbow is visible when the sun's rays striking upon water-drops are reflected to the observer. Concerning rocks he teaches that many at least of these are formed by deposit of finer or coarser particles from suspension in water, and during long periods of time become gradually consolidated. Da Vinci had made the same observation. Palissy collected fossils widely, and denounced the absurdity of attributing their origin to Noah's flood or to a freak of Nature; because he had convinced himself, and was prepared to demonstrate to others, that these could have arisen only from the building up of plants and animals; and that if mollusks are found on hills, why those hills were once plains and covered with water; and if the fossils are remains of marine mollusks, then the area which now contains them was once a sea, an open sea or some inlet of the sea. He then pointed out the contortion of strata, and tried to explain the contours of the earth's surface by the mutations of rock structure. That with the materials at his service it was then impossible to master so vast a subject, and that his opinions were often crude and even erroneous, is little or no detraction from the merit of his method and extraordinary insight. He taught that there were two kinds of water, that which is free from a stony quality and that which congeals; he names them exhalative and congelative waters respectively, and out of this comparison he is led to a conception of a fifth element, in terms which remind us of the theory of phlogiston. For all early chemists a will-o'-the-wisp inhabited the atmosphere, which in the eighteenth century was caught, examined, and named oxygen. To illustrate the action of 'congelative water' he collected a great number of stalactites; and for similar denonstrations he collected petrifactions.

Concerning earthquakes, he says that he had learned more of their nature from a kettle than all the professors could find in the books of the ancients; namely, that they consist in an imprisonment of water which is heated to ebullition in the bowels of the earth. 'This was the opinion of two no less wonderful men, his predecessors, of whom Palissy had probably never heard; namely, Da Vinci and, before him, Anthemius of Tralles, the architect of S. Sophia, who is said to have tried to prove his hypothesis by imprisoning steam under his neighbour's house. Palissy taught that every art, if widely and profoundly studied, has a fullness of science enclosed in it; a truth 

I have ventured to emphasize on more than one occasion against intemperate rebukes of 'specialism'. 'I am', he says, 'neither Greek nor Jew, neither poet nor rhetorician ; only a simple, humble-minded, ill-educated handicraftsman; but I read in the book of the heavens and the earth more than all the books of the philosophers could tell me.' Honesty obliges me not to conceal that at the physicians of his day he deals some shrewd blows; especially condemning their polypharmacy, which he says must be wrong; for none can calculate the effects of commingled ingredients, each of which must modify the action of the rest indefinitely.

But while this Calvinist preacher, this sapper of the Mosaic cosmogony, this scoffer at schools and faculties was making sermons of his insurgent stones, where were the agents of the League? Why, the League was wide awake; not even Catherine-remembering her Florentine love of beauty-and Henry could shield their favourite artist for ever. Other protectors were dead or palsied, so at the age of eighty the old man was thrown into the Bastille; and we have then the not unfamiliar but perhaps apocryphal story of the visit of the King to his old retainer. Henry, generous as in some aspects of thought and character he may have been, was, as we know but too well of him and of many other potentates, unfit to rise to the height of the needs of the times. These were the words which are said to have fallen from the royal mouth, words at any rate worthy of that monarch: 'Mon bonhomme, il y a quarante-cinq ans que vous êtes au service de la Reine ma Mère et de moi; nous avons enduré que vous ayez vecu en votre Religion parmi les feux et les massacres: maintenant je suis tellement pressé par ceux de Guise et mon peuple, qu'il m'a fallu malgré moi mettre en prison ces deux pauvres femmes et vous; elles sont brulées demain et vous aussi, si vous ne vous convertissez.' Bernard is said to have answered thus: 'Sire, le Comte de Maulevrier vint hier de votre part pour promettre la vie à ces deux scurs si elles voulaient vous donner chacune une nuit. Elles ont repondu qu'encore elles seraient martyres de leur honneur comme de celui de Dieu. Vous m'avez dit plusieurs fois que vous aviez pitié de moi, mais moi j’ai pitié de vous, qui avez prononcé ces mots. "J'y suis contraint", ce n'est parler en Roy. Ces filles et moi qui avons part au Royaume des Cieux, nous nous apprendrons ces mots royaux, ce langage royal, que les Guisarts, tout votre peuple, ni vous, ne sauriez contraindre un potier à fléchir les genoux devant des Statues.' He is said to have added that to compel him was impossible, for he knew how to die; but it is not unlikely that at any: rate these words of Seneca, 'Qui mori scit, cogi nescit,' were 



\subsection{PROCEEDINGS OF THE BRITISH ACADEMY}

added to him by later tradition. In the following year Henry fled to Navarre, soon after to meet the retribution his recreancy and debauchery deserved; and Palissy died a natural death in prison, but a death probably accelerated by enmity, hardship, and neglect.

The enmity of the League, the triumph of reaction after Henry the Fourth, and the jealousy of the University and the Sorbonne took good care that Palissy's methods should be thrust into oblivion. That this was so we learn indirectly from the fate of a work by one Etienne de Claves, Doctor of Medicine, entitled Paradoxes ou Traités Philosophiques des Pierres et Pierreries, contre Topinion vulgaire, Paris, 1635, a book based on the teaching of Palissy; de Claves was harassed by persecution, and his book publicly destroyed. Thus it has happened that, in spite of some justice done to Palissy as an art craftsman by later French writers, his reputation as a pioneer in natural science lies still in eclipse. Palissy moreover had offended, not the priests and the philosophers only, but also the astrologers and alchemists; and these charlatans did not fail to take their revenge. And there is the less dishonourable cause for the neglect of this great side of his life that Palissy's works as an artist were more popular and attractive than his persistent and original devotion to natural science, which, even in our day, the public might be disposed to set down to the cranks of a curious genius. In 1674. Perrault cursorily noted Palissy's theory of springs; but from that time forward, as a naturalist, Palissy was forgotten till Fontenelle, Jussieu, Buffon, and Cuvier endeavoured to vindicate his due place in history. De Jussieu, in 1718, pointed out that, 150 years before, Palissy, of his own unaided wit and observation, had taught that Sicily and England, containing fossils, must at one time have been covered with water. And Buffon said, 'a simple potter of the end of the sixteenth century was the first to dare to tell Paris and the Doctors that marine fossils were true animal remains, were deposited in a sea in the place where they now are found, and were born of their respective animal parents. This he defied the Aristotelians to deny.' Réamur offered the same testimony. Yet even to-day these historical facts are almost unknown. In a recent address on the history of geology one of the most distinguished and accomplished living geologists did not even allude to Palissy, the founder of that branch of science. Another very eminent geological professor told me he had never heard of Palissy, except as a potter. It was by the needs of his art that Palissy was obliged to work in earths and minerals, and, endowed with a mind far more powerful than that of 

ordinary practical men, he brought the vivid insight and the simplicity of genius to the interpretation of their phenomena. Cuvier says of Palissy's observations, 'C'est là, comme on voit, le commencement, l'embryon de la géologie modeme ... la question générale, de savoir comment se sont superposées ces immenses croûtes qui constituent aujourd'hui les parties solides du continent, n'avait pas encore été agitée.' Cuvier goes on to say that only by a study of fossils could this problem be solved; and then he proceeds: 'Des hommes prétendaient, dans le quinzième et le seizième siècle, que c'était un résultat des jeux de la nature, un produit de ses forces naturelles, des aberrations de sa puissance vivifiante; Palissy expulsa ces erreurs du domaine de la science.' Yet, a few months ago, on entering the University Library, I picked up a volume entitled Karl Ernst Adolf von Hoff, der Bahnbrecher moderner Geologie, von Otto Reich, 1905. The author begins, of course, as a good German should, with the Chaldeans; runs through Greepks and Alexandrians, attacks the Church as the tyrannical suppressor of all science, and then takes us down to Linnaeus and Buffon as the originators of geology. Descartes is mentioned: Steno is mentioned. His hero, von Hoff, was born in the classical shades of Gotha in 1778, and thus he descends the historical stream to Werner and Hutton; but the name of Palissy is not to be found in the book. Well night Buffon say that Bernard Palissy was a natural investigator so great as Nature only fashions once; yet his teaching had slept for a hundred years. However, strangely enough, the ancients had read some of these signs; and a very interesting comparison might be made between some of his conceptions and those of $\mathrm{Da}$ Vinci -who lived a hundred years before him. The ancients, not locked up in the Mosaic cosmogony, had a freer outlook, and were not forbidden to believe their own eyes: but even their. ideas were perhaps entirely caprices of fancy to which we, by importing into them our own interpretations, have given factitious values; as, for example, to the wellknown passage of Ovid, in the Metamorphoses, where the poet describes a vision of once solid earth become ocean, of lands made into seas, and of marshes turned into sandy desert. Also of shells found upon mountain tops, to which list of fossils however he adds an ancient anchor.

As to Palissy's style, modern readers, besides their surprise at the novelty and variety of his observations, have compared its personal quality even with Montaigne. Cynic however Palissy is not, nor even a sceptic; he is throughout a constructive spirit ; but he has the vivid picturesqueness of Montaigne, ${ }^{1}$ the same shrewd wit, the same spontaneous, free, and humorous apprehensions. His style is seen at

1 As best seen in the Journal of his Travels. 



\section{PROCEEDINGS OF THE BRITISH ACADEMY}

its best in his book on pottery, where he describes his strifes with difficulties, and his failures.

Of Palissy's minor writings I may, as illustrations of his grip of facts and lucid intelligence, mention his tracts in denunciation of mithridatics and theriacs; remedies which, gross and foolish as they seem to us, in the sixteenth century had enormous vogue, and even up to the end of the eighteenth were administered by routine in certain hospitals; for instance in Montpellier. It may be that even Paré was much influenced by Palissy ; if not initiated into his repudiation of unicorn as an antidote to poison by Palissy, who also exposed its futility, he was supported in it. Palissy also wrote a severe indictment of my own profession, entitled Les Abus des Médecins ${ }^{2}$; in which I will not seek for naughty words concerning these estimable men; but I will quote from it another remarkable anticipation of modern scientific theory. He says: 'If you were a good philosopher you would know that the elements cannot destroy each other; they can only predominate one over the other according to the conditions of the moment. Water may drive fire away, or fire water; but neither can destroy the other, or consume it; the elements cannot be diminished or augmented. If it were otherwise-that the one could consume the other-we should for long enough have been deprived of the due measure of certain elements ;' and so on.

It is now time for me to enter upon a most interesting historical problem, namely, of the probable intellectual relation of Palissy to Francis Bacon. I have said that in the years 1575-84. Palissy, having amassed a large collection of objects of natural history, of rocks and minerals, of fossils, and of various earths, and having attached to every specimen a label and description, gave formal lectures with practical demonstrations on these objects, and interpreted them with an acumen and a truth of observation and argument which at that period was without parallel or compare. These lectures, as we have seen, became the fashion, and being delivered by no obscure potter but by a well-known person about the court-namely, Master Bernard of the Tuileries-were attended by large audiences of the first men of the day in Paris. Now we know that in the year 15\%6 Francis Bacon left Cambridge, disgusted, so the story goes, with the dialectic of the schools, and ready to welcome some new and fruitful method of learning. It is not probable at this time of his youthCommorant in the University, says Dr. Rawley, at sixteen years of age - that he had conceived what this new and fruitful method should

1 It seems in the light of later researches that the tract entitled Les déclurations des abus et ignorances des médecins is spurious. 

be; but he was yearning for something better than the stereotyped routine of the schoolmen. Now in this year 1576 it happened that Bacon went to Paris with Sir Amyas Paulet, and there resided for three years, during the first two of which he was attached to the English Embassy, whither all news would find its way. And in his keenness for new sources of knowledge Bacon must have heard of these notorious lectures, delivered by a royal officer who was also a Huguenot and reformer, who was challenging all comers to gainsay him, and was loudly proclaiming precisely such a new method as we presume Bacon to have been then in search of. At that date Master Bernard's Museum was the first collection of the kind in modern Europe, and the scheme of its arrangement and labelling was as enlightened as that of the most recent museums of our own day; and far superior to that of fifty years ago-as many of us can personally testify. That Bacon, being in this mind, was not attracted to these curiosities, and to these provocative lectures and demonstrations seems inconceivable. Science or no science, whithersoever the great men of the day went we may be pretty sure that Bacon went also. But, it may be objected, Bacon has said nothing of Palissy or his lectures. Well, directly perhaps not: indirectly perhaps he did. What we do know is ${ }^{1}$ that, on the morrow of his return to England, Bacon published a tract entitled Temporis partus maximus, a tract unhappily now lost, and from which unluckily we have no definite excerpts. Of its contents we know so little that but for the allusion to it by Bacon himself in his letter to Fulgenzio it would have been forgotten. In 1625 Bacon stated that he had published this tract about forty years before. Now forty years before 1625 was 1585; Bacon, as we have seen, returned to England in 1589, and it was about this date that the tract was published. Bacon himself calls it a 'juvenile work which with great confidence and a magnificent title I named The Greatest Birth of 'Time'. It seems then to have been a crude and rather turgid -in other words, a youthful-production in which the author, with fresh ardour, proclaimed a new method of attaining knowledge; and this, as we are justified in assuming, was by the collection, observation, interpretation, and proof of natural phenomena and processes. Now, short of demonstration, can any probability be stronger than this-that Bacon, hungering for a more fruitful method

1 I had independently arrived at the facts and opinions set forth in this paper up to this point. For the reference to the Temporis partus maximus I am indebted to Hanschmann's Essay on Bernard Palissy, Leipzig, 1903. My paper was read to the Eranus Club at Cambridge before Hanschmann's work was published. 



\section{PROCEEDINGS OF THE BRITISH ACADEMY}

than the droning of the schools, during his residence in Paris went to the lectures and inspected the Museum of Palissy, Palissy who was defying the schoolmen as fervently as Bacon himself could have desired, and who was moreover constructing the new method of direct investigation of nature by facts; that Bacon was fired by this revolutionary teaching, and in the heat of his illumination wrote the inmature and vaunting proclamation of the new gospel, which afterwards he redigested and developed into the magnificent structure of the Instauration? What is certain is that Palissy was then teaching practically the methods which a few years afterwards Bacon propounded at length; and, not only so, but was teaching them, if with a far inferior literary capacity, yet with a sounder grasp of their methods. For is it too paradoxical to say that as Palissy was among the first of the men of science, Bacon was one of the last of the schoolmen? He was still a schoolman in his encyclopaedic conceptions, in the philosophizing habit of his mind, in his crude apprehension of methods of natural observation and experiment, and in his incapacity for appreciation of genuine natural research in those of his contemporaries who were not compiling new instaurations but building up the foundation of natural knowledge-such men, for instance, as Harvey and Kepler whom he ignored; Copernicus whom, with his disciple Bruno who on Bacon's return was actually in London, he shirked; Gilbert whom he classed with the alchemists; Galileo whom he attacked. Unfortunately, as Kuno Fischer admits, Bacon was no mathematician; now natural science found its first solid foundation in physics, and physics in mathematics.

But, it may be said, surely if Bacon had been so inspired by Palissy he would have mentioned him, and held him in honour. Now it is unnecessary to ask ourselves how far Bacon's intellectual character, so far as we can read it, was that of a man who was likely to pay a generous tribute to any forerunner; or how far his moral character would dispose him to declare himself a disciple of a reformer notoriously under the suspicion of the ruling classes in Paris, and preserved from instant peril only by the personal intervention of Montmorency and the King. Such generosity the history of Bacon's life scarcely suggests to us. But it is unnecessary to press these painful questions; it is sufficient to remember that even so late as the sixteenth century plagiarism was unknown as a sin, and, according to the code then prevailing, literary debts were not even debts of honour. Even the honest and gentle Paré himself did not hesitate to borrow freely from the works of his contemporaries; and when in a particular instance Paré was reminded that he had drawn freely upon the work of his 

contemporary De Héry, Paré calmly replied that a candle must always be lit at another candle. Bacon makes no mention of Ramus, to whom Professor Jackson thinks he was deeply indebted; that he expresses no debt to Palissy is therefore of little weight in our inquiry into those obligations to forerunners and contemporaries of which not the greatest of men have been independent. To learn what Palissy was actually teaching in Paris during Bacon's residence there, it is necessary only to turn to the full title of the Discours admirables, which I have already cited at length. It would be misleading, no doubt, to compare a contemplative reformer of philosophic methods with a working naturalist like Palissy; and it would be untimely to enter upon a criticism of the validity of Bacon's positions taken as a whole; yet it may be permitted to me to say that however imposing his philosophic system, however impressive in turning men from stereotyped scholastic dogma, yet Palissy-like his contemporary Gilbert, and like Galileo who came very soon after himwas one of the chief engineers of the new paths of knowledge, and was in France the chief engineer. Indeed, astronomy and mathematics apart, he with Dodoens and Gesner were the first in Europe since Aristotle, Theophrastus, and Pliny, to pursue modern scientific methods in the worlds of geology, botany, and zoology, and to work and teach from and with the natural objects themselves. 
PLEASE DO NOT REMOVE CARDS OR SLIPS FROM THIS POCKET

\section{ERINDALE COLLEGE LIBRARY}

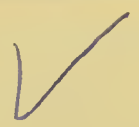


